\title{
Regulatory Mechanisms of Growth Hormone Secretion Are Sexually Dimorphic
}

\author{
Craig A. Jaffe, ${ }^{\star}$ Blanca Ocampo-Lim, ${ }^{*}$ Wensheng Guo, ${ }^{\ddagger}$ Kathryn Krueger, ${ }^{*}$ Ikuko Sugahara, ${ }^{*}$ Roberta DeMott-Friberg, ${ }^{*}$ \\ Martin Bermann, ${ }^{*}$ and Ariel L. Barkan* \\ *Division of Endocrinology and Metabolism, Department of Internal Medicine, Department of Veterans Affairs Medical Center and \\ University of Michigan Medical Center, Ann Arbor, Michigan 48109-0354; and ${ }^{\ddagger}$ Department of Biostatistics, School of Public Health, \\ University of Michigan, Ann Arbor, Michigan 48109-2029
}

\begin{abstract}
Sexually dimorphic growth hormone (GH) secretory pattern is important in the determination of gender-specific patterns of growth and metabolism in rats. Whether GH secretion in humans is also sexually dimorphic and the neuroendocrine mechanisms governing this potential difference are not fully established. We have compared pulsatile GH secretion profiles in young men and women in the baseline state and during a continuous intravenous infusion of recombinant human insulin-like growth factor I (rhIGF-I). During the baseline study, men had large nocturnal GH pulses and relatively small pulses during the rest of the day. In contrast, women had more continuous $\mathrm{GH}$ secretion and more frequent $\mathrm{GH}$ pulses that were of more uniform size. The infusion of rhIGF-I $(10 \mu \mathrm{g} / \mathrm{kg} / \mathrm{h})$ potently suppressed both spontaneous and growth hormone-releasing hormone (GHRH)-induced GH secretion in men. In women, however, rhIGF-I had less effect on pulsatile GH secretion and did not suppress the GH response to GHRH. These data demonstrate the existence of sexual dimorphism in the regulatory mechanisms involved in GH secretion in humans. The persistence of GH responses to GHRH in women suggests that negative feedback by IGF-I might be expressed, in part, through suppression of hypothalamic GHRH. (J. Clin. Invest. 1998. 102:153-164.) Key words: pituitary • hypothalamus $\bullet$ human • insulin-like growth factor I • thyroid-stimulating hormone
\end{abstract}

\section{Introduction}

The sexual dimorphism of growth hormone $(\mathrm{GH})^{1}$ secretion in rats has been extensively studied. High amplitude GH pulses and low interpulse GH concentrations characterizes GH profiles in males, whereas female rats have less regular pulses and higher interpulse $\mathrm{GH}$ levels (1). These differences have physiologic importance and are responsible for the differential expression of sex-specific, hepatic P450 drug-metabolizing en-

\footnotetext{
This paper was presented in part at the 77th Annual Meeting of the Endocrine Society, 14-17 June 1995, Washington, DC.

Address correspondence to Craig A. Jaffe, M.D., Division of Endocrinology and Metabolism, University of Michigan Medical Center, 3920 Taubman Center, 1500 Medical Center Drive, Ann Arbor, MI 48109-0354. Phone: 313-936-5504; FAX: 313-936-9240; E-mail: cjaffe@umich.edu

Received for publication 26 January 1998 and accepted in revised form 16 April 1998.
}

The Journal of Clinical Investigation

Volume 102, Number 1, July 1998, 153-164

http://www.jci.org zymes (2) and for male-female differences in growth rate (3). Potential differences in $\mathrm{GH}$ secretion in humans have been less well studied.

Women were found to have higher average daily GH concentrations by some (4-6) but not all (7) investigators. A recent study using deconvolution analysis to estimate $\mathrm{GH}$ secretion found twofold higher $\mathrm{GH}$ secretion rates in middle-aged women compared with men of a similar age (6); in addition, women appear to secrete GH with more "process irregularity" than men (8). Whether there is a gender-based difference in pituitary sensitivity to GH-releasing hormone (GHRH) is unclear; it has been reported that women have greater (9), smaller (10), or equivalent $(11,12) \mathrm{GH}$ responses to GHRH compared with men. It is also uncertain whether there is sexual dimorphism in the $\mathrm{GH}$ responses to provocative pharmacologic testing. Gender differences during testing with pyridostigmine or insulin were observed by some $(13,14)$ but not all investigators (12). In addition, one study convincingly demonstrated that $\mathrm{GH}$ suppression after ingestion of oral glucose was less complete in women than in men (15). Potential mechanisms underlying gender differences in $\mathrm{GH}$ secretion have been recently reviewed (16) and might include differences in GH clearance, in GHRH or somatostatin (SRIH) secretion, or in negative feedback at the level of the pituitary or hypothalamus by GH or insulin-like growth factor I (IGF-I).

Accurate analysis of potential sex-specific patterns of $\mathrm{GH}$ secretion has been limited by study design or by methodology. Some of the daily GH secretion data were obtained using infrequent blood sampling (5) or relatively insensitive $\mathrm{GH}$ assays that did not allow accurate resolution of $\mathrm{GH}$ pulsatility in the low assay range (4). One study used a continuous blood draw technique, so potential gender-related differences in $\mathrm{GH}$ secretion pattern could not be ascertained (7). In addition, heterogeneous subject populations, the interdependent variables of age and relative adiposity, the wide range of estradiol (E2) concentrations observed in study subjects, and a sex-specific effect of age on GH secretion (17) might have each played a role in the conclusions reached in the various studies.

In this study, we have defined gender-specific patterns of spontaneous and GHRH-stimulated GH secretion through intensive blood sampling and use of a super-sensitive $\mathrm{GH}$ assay in carefully selected groups of young men and women. In addition, we have investigated whether negative feedback by IGF-I on GH secretion is the same in men and women.

1. Abbreviations used in this paper: $\mathrm{BPF}$, block-GH pulse frequency; BTI, block-total GH input; E2, estradiol; GH, growth hormone; GHRH, growth hormone-releasing hormone; IGF-I, insulin-like growth factor I; IGFBP-3, IGF binding protein 3; rhIGF-I, recombinant human IGF-I; P, progesterone; SRIH, somatostatin; TRH, thyrotropin-releasing hormone; $\mathrm{TSH}$, thyroid-stimulating hormone; $\mathrm{T} 3$, triiodothyronine; T3RU, triiodothyronine resin uptake; T4, thyroxine. 


\section{Methods}

Subjects. The research protocol was approved by the Institutional Review Board and the General Clinical Research Center Operating Subcommittee of the University of Michigan Hospitals. Written consent was obtained from each subject before their participation. Eight healthy men and eight healthy women were recruited. The two groups were of similar age $(23.5 \pm 2.9$ vs. $25.2 \pm 4.0 \mathrm{yr}$; mean $\pm \mathrm{SD}$; men vs. women) and body mass index (23.8 \pm 0.9 vs. $\left.22.9 \pm 2.9 \mathrm{~kg} / \mathrm{m}^{2}\right)$. All had unremarkable medical histories and physical examinations. Measurements of renal, hepatic, and hematological function in all subjects were normal. None of the subjects were on any medications. Only women with regular spontaneous menstrual cycles were included. Women were studied during the early follicular phase of the cycle and menstrual status was further validated by measurement of serum estradiol (E2) and progesterone (P) concentrations.

Protocol. The subjects were admitted to the GCRC the evening before the actual study and antegrade intravenous cannulae were placed in forearm veins of each arm. The subjects were fed three meals each day served at 0700,1200 , and $1800 \mathrm{~h}$, respectively. Caloric content was standardized as previously described (18). Lights were turned on at $0630 \mathrm{~h}$ and off at $2300 \mathrm{~h}$. Daytime napping was not allowed.

Eight men were each studied twice, once while receiving normal saline (control) and once while receiving recombinant human IGF-I (rhIGF-I; Genentech, South San Francisco, CA). Data on six of these men during the control saline infusion and on four men during the infusion of $10 \mu \mathrm{g} / \mathrm{kg} / \mathrm{h}$ rhIGF-I have been previously reported (18). Two additional men were studied using saline and $10 \mu \mathrm{g} / \mathrm{kg} / \mathrm{h}$ rhIGF-I. Both studies in the men were performed during the same admission as previously described (18). In brief, every $10 \mathrm{~min}$, blood sampling was done for $\mathrm{GH}$ from $0800 \mathrm{~h}$, day 1 until $1200 \mathrm{~h}$, day 2 . At $0800 \mathrm{~h}$, day 2, an i.v. bolus of $50 \mu \mathrm{g}$ thyrotropin-releasing hormone (TRH, Thypinone; Abbot Laboratories, North Chicago, IL) was given. This was followed by administration of an i.v. bolus of $0.33 \mu \mathrm{g} / \mathrm{kg}$ human GHRH-44 (Bachem California, Torrance, CA) at $1000 \mathrm{~h}$. After completion of the GHRH test at $1200 \mathrm{~h}$, an infusion of $10 \mu \mathrm{g} / \mathrm{kg}$ body weight/h rhIGF-I was begun and continued until $1200 \mathrm{~h}$, day 4 . Every $10 \mathrm{~min}$, sampling for $\mathrm{GH}$ was again performed from $0800 \mathrm{~h}$, day 3 until $1200 \mathrm{~h}$, day 4. I.v. boluses of TRH and GHRH were given on day 4 in doses and times identical to that on day 2. For the women, a similar protocol was followed; however, the saline and IGF-I studies were performed in random order during the early follicular phase of different menstrual cycles. Care was exercised to match the timing of saline and rhIGF-I infusion to the same day of the menstrual cycle and women were admitted to the GCRC for study within $48 \mathrm{~h}$ of the onset of menses. For both men and women, plasma IGF-I was measured at 4-h intervals during the saline and IGF-I infusions. Plasma samples for total thyroxine (T4), T3 resin uptake (T3RU), and total triiodothyronine (T3) were obtained just before the TRH administration. Blood was sampled every $20 \mathrm{~min}$ for thyroid-stimulating hormone (TSH) from times -20 to +60 min with respect to the TRH bolus. Plasma E2, P, and testosterone (T) were measured in a sample made by pooling equal aliquots of plasma obtained every $6 \mathrm{~h}$ during the period of frequent blood sampling.

Assays. Plasma GH was measured in duplicate by a chemiluminescent assay (Nichols Institute Diagnostics, San Juan Capistrano, CA) that is specific for $22 \mathrm{kD} \mathrm{GH}$ as previously described (19). All samples from each particular subject were analyzed in the same assay and the detection limit of the assay was $0.01 \mu \mathrm{g} /$ liter. Mean intraassay coefficient of variation $(\mathrm{CV})$ was $9 \%$ between 0.01 and $0.1 \mu \mathrm{g} / \mathrm{liter}$ and $5 \%$ between 0.1 and $40 \mu \mathrm{g} / \mathrm{liter}$. Interassay CV was $7 \%$ at $9 \mu \mathrm{g} / \mathrm{li}-$ ter. rhIGF-I at a concentration of $1,000 \mu \mathrm{g} /$ liter did not interfere with the measurement of GH. Total IGF-I was measured after acid-ethanol extraction by an immunoradiometric assay (Diagnostics Systems Laboratories; Webster, TX) and IGF binding protein-3 (IGFBP-3) was measured using RIA kits (Diagnostics Systems Laboratories). All IGF-I measurements for a particular patient were performed in a single assay and the interassay and mean intraassay coefficients of variations were 6 and 5\%, respectively. Plasma E2, P, and T were measured using commercial kits (Coat-A-Count, Diagnostics Products Corporation; Los Angeles, CA). All measurements of IGFBP-3, $\mathrm{E} 2, \mathrm{P}$, and $\mathrm{T}$ were performed in single assays. Total $\mathrm{T} 4$, total $\mathrm{T} 3$, T3RU, and TSH assays were performed by the Ligand Laboratory of the University of Michigan Medical Center using standard methodologies.

Data analysis. Integrated GH concentration (in micrograms $\times$ minute per liter) was calculated as the area under the GH vs. time curve using the trapezoidal rule. This was performed for the time period $0800-0800 \mathrm{~h}$ during both saline and IGF-I infusions. The GH responses to GHRH and the TSH responses to TRH were defined as maximal increases in the hormone concentrations over the baseline.

Parameters of GH pulsatility were analyzed with regard to both concentration and secretion. Cluster analysis was used to define peaks in the plasma $\mathrm{GH}$ concentration profiles as previous described (18). An absolute nadir was defined as the minimum GH concentration over $24 \mathrm{~h}$ for individual subjects. Wave form-dependent deconvolution analysis (20) of the 24-h GH profiles was used to calculate GH half-life, GH pulse frequency, and GH secretion profile. The absolute $\mathrm{GH}$ nadir in each series was assumed to reflect basal GH secretion. Daily GH secretion (micrograms per 24 hours) was calculated as the daily GH secretion (micrograms per liter) times the total volume of distribution $\left(\mathrm{L}_{\mathrm{v}}\right)$, which was assumed to be $7.9 \%$ of body weight (21). GH concentrations and discrete parameters of pulsatile GH secretion were compared between men and women during saline and IGF-I treatments using two-tailed, two-sample $t$ tests.

As a measure of uniformity of GH pulse amplitude, a SD for each subject's $\mathrm{GH}$ pulses during the baseline study was calculated. $\mathrm{GH}$ pulse amplitudes were logarithmically transformed before analysis. A similar analysis was performed after logarithmic transformation of the 145 daily GH concentrations. To determine whether the daily GH secretion pattern differed between men and women, we divided the 24-h sampling period into eight 3-h blocks and calculated the blocktotal GH input (BTI) and the block-GH pulse frequency (BPF) based on the estimates from deconvolution. These data were analyzed by repeated measures ANOVA. The percent of the day spent in actual active $\mathrm{GH}$ secretion was calculated from the deconvolution output.

Table I. Comparison of 24-Hour GH Secretion Parameters between Men and Women

\begin{tabular}{|c|c|c|c|}
\hline Parameter & $\begin{array}{c}\text { Men } \\
(n=8)\end{array}$ & $\begin{array}{l}\text { Women } \\
(n=8)\end{array}$ & $P$ \\
\hline \multicolumn{4}{|l|}{ GH concentration analysis (cluster) } \\
\hline IGHC $(\mu \mathrm{g} \times \min /$ liter $)$ & $2884 \pm 661$ & $3621 \pm 613$ & NS \\
\hline Mean pulse amplitude ( $\mu \mathrm{g} /$ liter $)$ & $5.2 \pm 0.8$ & $3.8 \pm 0.7$ & NS \\
\hline Median pulse amplitude ( $\mu \mathrm{g} /$ liter $)$ & $1.3 \pm 0.3$ & $1.5 \pm 0.2$ & NS \\
\hline \multicolumn{4}{|l|}{ Maximum pulse amplitude } \\
\hline ( $\mu \mathrm{g} /$ liter) & $24.1 \pm 3.6$ & $12.1 \pm 2.6$ & 0.017 \\
\hline Mean valley ( $\mu \mathrm{g} /$ liter $)$ & $0.13 \pm 0.02$ & $0.28 \pm 0.03$ & 0.001 \\
\hline Absolute nadir ( $\mu \mathrm{g} /$ liter $)$ & $0.06 \pm 0.01$ & $0.07 \pm 0.01$ & NS \\
\hline Pulse frequency (per 24 h) & $8.2 \pm 0.8$ & $10.3 \pm 0.5$ & 0.05 \\
\hline SD of pulse amplitudes ( $\mu \mathrm{g} /$ liter $)$ & $7.98 \pm 1.10$ & $5.31 \pm 1.04$ & 0.001 \\
\hline \multicolumn{4}{|l|}{ GH secretory analysis (deconvolution) } \\
\hline \multicolumn{4}{|l|}{ Daily GH secretion rate } \\
\hline$\left(\mu \mathrm{g} / \mathrm{L}_{\mathrm{V}}\right.$ per $\left.24 \mathrm{~h}\right)$ & $93.2 \pm 20.8$ & $105.0 \pm 14.8$ & NS \\
\hline Total GH secreted $(\mu \mathrm{g} / 24 \mathrm{~h})$ & $561 \pm 130$ & $514 \pm 88$ & NS \\
\hline Pulse frequency (per 24 h) & $10.8 \pm 1.1$ & $19.9 \pm 2.3$ & 0.005 \\
\hline \multicolumn{4}{|l|}{ Total duration of pulsatile } \\
\hline GH half-life (min) & $16.5 \pm 0.6$ & $18.1 \pm 1.0$ & NS \\
\hline
\end{tabular}


Repeated measures ANOVA was performed to determine the effects of gender and of rhIGF-I on GH secretion and the potential interaction between these two factors. The effects of rhIGF-I on sex steroids, IGFBP-3, and thyroid hormones were analyzed by paired $t$ tests. In all comparisons, data that were not normally distributed were logarithmically or square root transformed as appropriate before analyses. $P<0.05$ was considered statistically significant. Data are presented as mean $\pm \mathrm{SE}$.

\section{Results}

Baseline GH secretion. A comparison of 24-h GH concentration and secretion parameters between men and women during the control day is presented in Table I. Total daily GH secretion as measured by 24 -h IGHC was similar between the two genders. Women had marginally more pulses $(P=0.05)$. There were no differences between men and women with regard to either mean or median pulse amplitude, but the maximum pulse amplitude was greater in men $(P=0.017)$. Although the nadirs for the 24-h baseline studies were similar in the two groups $(P=0.5)$, mean $\mathrm{GH}$ valley concentrations were twice as high in women $(P=0.001)$.

Similar to the results of the 24-h IGHC, the deconvolution analysis also demonstrated that total $\mathrm{GH}$ input was indistinguishable between the two groups $(P=0.46)$. Total daily $\mathrm{GH}$ production rate was also identical in the two groups $(P=$ $0.77)$. Men had fewer GH secretory events per 24 hours than did women $(10.8 \pm 1.1$ vs. $19.9 \pm 2.3$ secretory pulses $/ 24 \mathrm{~h} ; P=$ 0.005). Deconvolution-estimated GH half-life and mean secretory amplitude were similar in the two groups. The only significant association found by regression analysis of mean $\mathrm{GH}$ with plasma E2, P, T, and IGF-I was a positive correlation between $\mathrm{GH}$ and $\mathrm{E} 2$ in men $\left(r^{2}=0.63 ; P=0.02\right)$.

Although there were no gender-related effects on total $\mathrm{GH}$ secretion, there were clear differences in the pattern in which men and women secreted the hormone. In Fig. 1, representative $\mathrm{GH}$ concentration profiles of two men and two women are plotted on linear (top) and logarithmic (middle) scales. Decon-
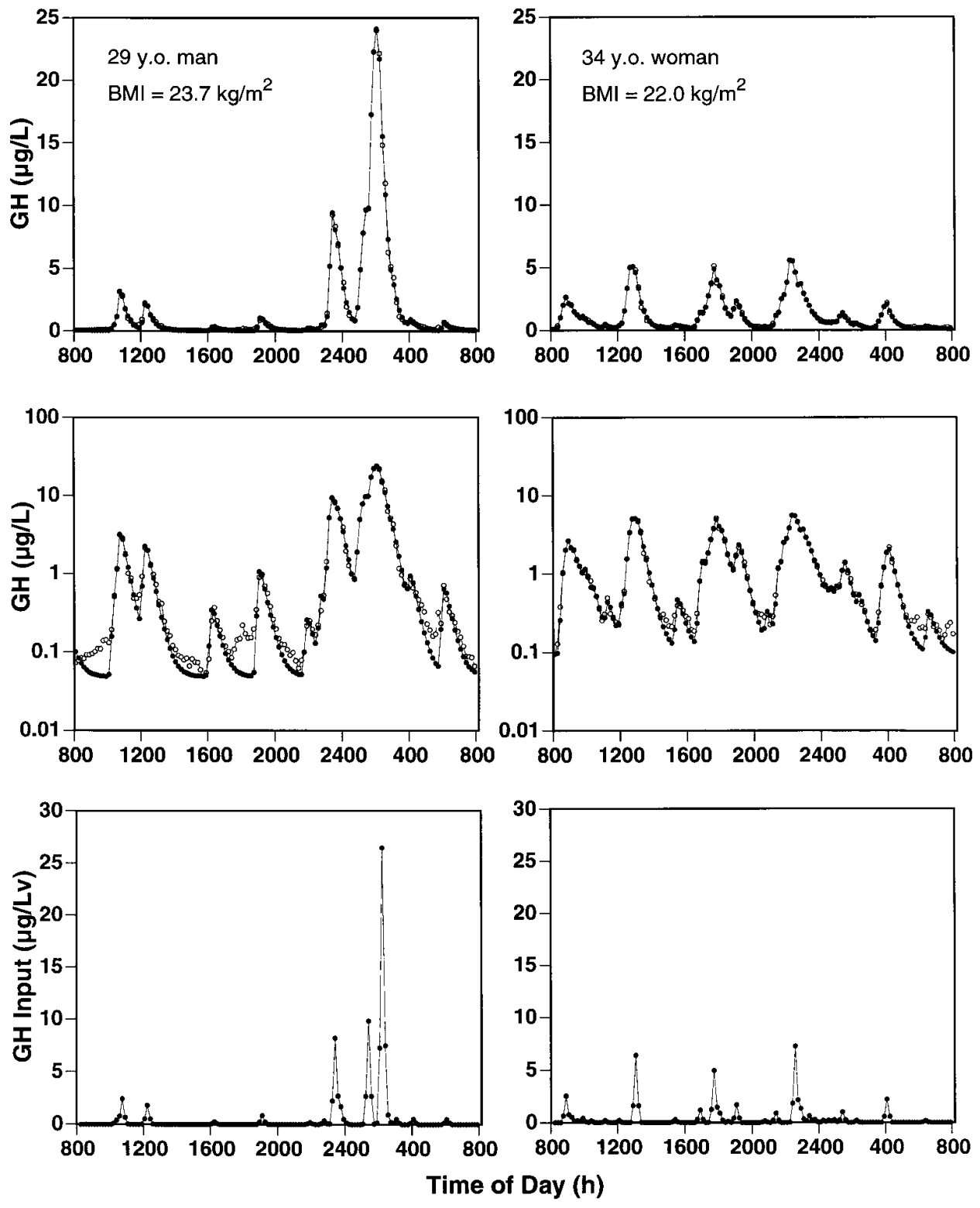

Figure 1. Representative 24-h GH concentration and secretion profiles from a man (left) and a woman (right). Measured GH concentrations $(\bigcirc)$ and the deconvolution fitted GH concentrations $(\bullet)$ are plotted on linear (top) and logarithmic (middle) scales. (Bottom) GH secretion calculated by deconvolution for these two subjects. 

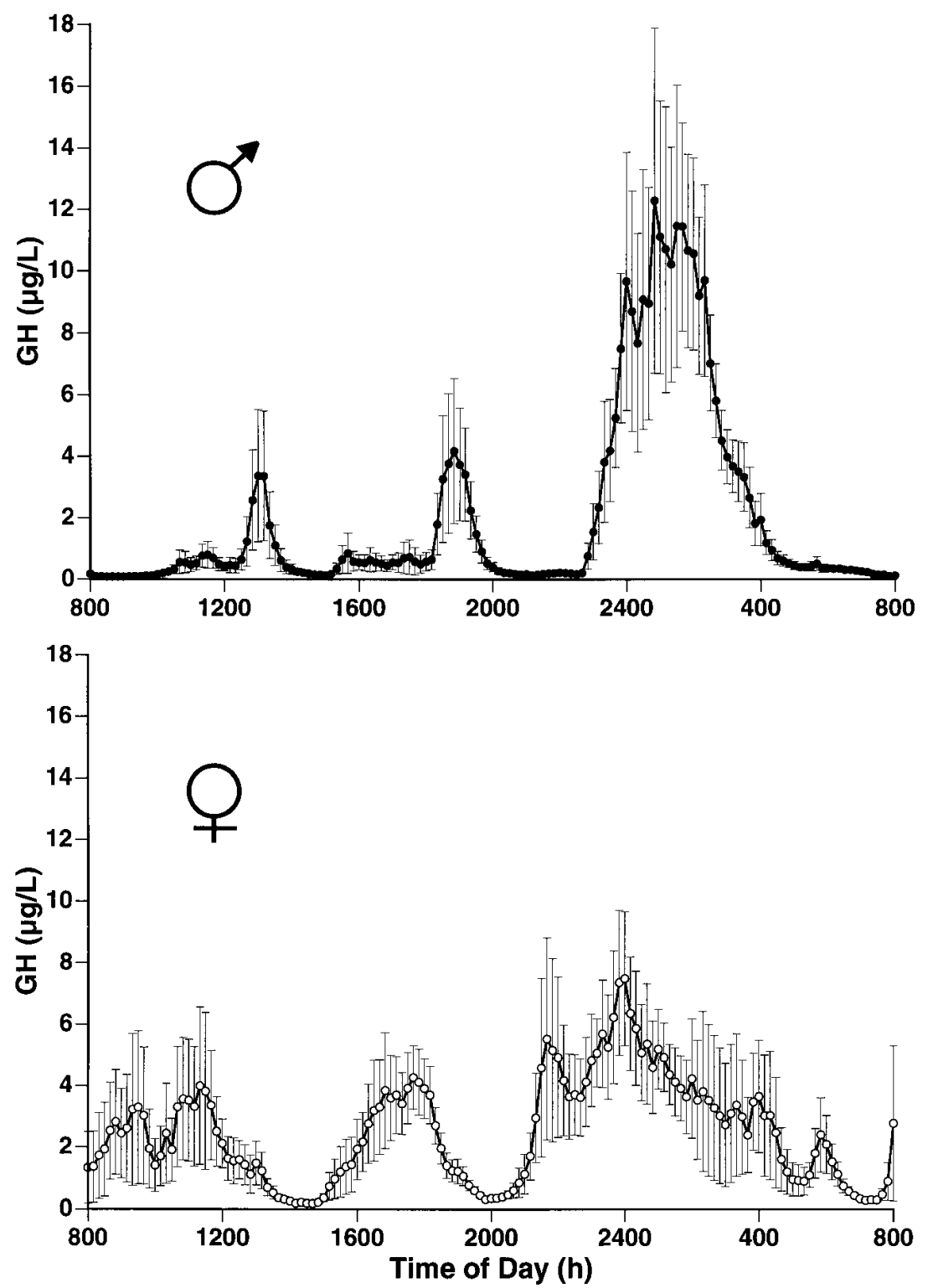

Figure 2. Composite picture of plasma GH concentration profiles (mean $\pm \mathrm{SE}$ ) in eight men (top) and eight women (bottom) during saline infusions.

volution-estimated $\mathrm{GH}$ secretory patterns are plotted in the bottom panel and the $\mathrm{GH}$ concentrations derived from these secretion estimates are overlaid on the measured concentration profiles. The mean $( \pm \mathrm{SE}) \mathrm{GH}$ concentrations for the eight men and eight women are given in Fig. 2. The 24-h profiles in men were characterized by the presence of a dominant nocturnal pulse with much smaller pulses at other times of the day. In contrast, $\mathrm{GH}$ secretion in women was more continuous, with pulses of similar amplitude throughout the $24 \mathrm{~h}$.

Several methods were used to quantify the differences in the pattern of GH secretion in men and women (Table I). As a measure of uniformity of pulse amplitude, a SD for each subject's GH pulse amplitudes during the baseline study was calculated. GH pulse amplitudes were logarithmically transformed before analysis. This estimate of variation was greater in men than in women (7.98 vs. $5.31 \mu \mathrm{g} /$ liter; $P=0.001)$. A similar analysis was performed after logarithmic transformation of the 145 daily GH concentrations. A higher SD for daily
GH was found in men (5.22 vs. $4.03 \mu \mathrm{g} /$ liter; $P=0.04)$. Fig. 3 shows a histogram of $\mathrm{GH}$ concentrations in these two groups. $\mathrm{GH}$ concentrations were either equal to or above the assay detection limit $98 \%$ of the time in men and $100 \%$ of the time in women. Although there was no difference between men and women in terms of absolute GH nadir, there was a difference in the frequency of biologically low GH concentrations. Reutens et al. (22) recently reported that subjects with severe organic $\mathrm{GH}$ deficiency had virtually all plasma $\mathrm{GH}$ concentrations $<0.5 \mu \mathrm{g} /$ liter during 24-h sampling. Using this value as an estimate of the minimum GH concentration for bioactivity, only $35 \pm 4 \%$ of the spontaneous plasma GH measurements in men were above this value, whereas $53 \pm 6 \%$ of the concentrations in women exceeded this limit $(P=0.04)$.

Deconvolution was used to determine differences in $\mathrm{GH}$ secretion that would account for gender-specific GH concentration profiles. Fig. 4 (top) shows the BPF for men and women calculated as the deconvolution estimated pulse fre- 


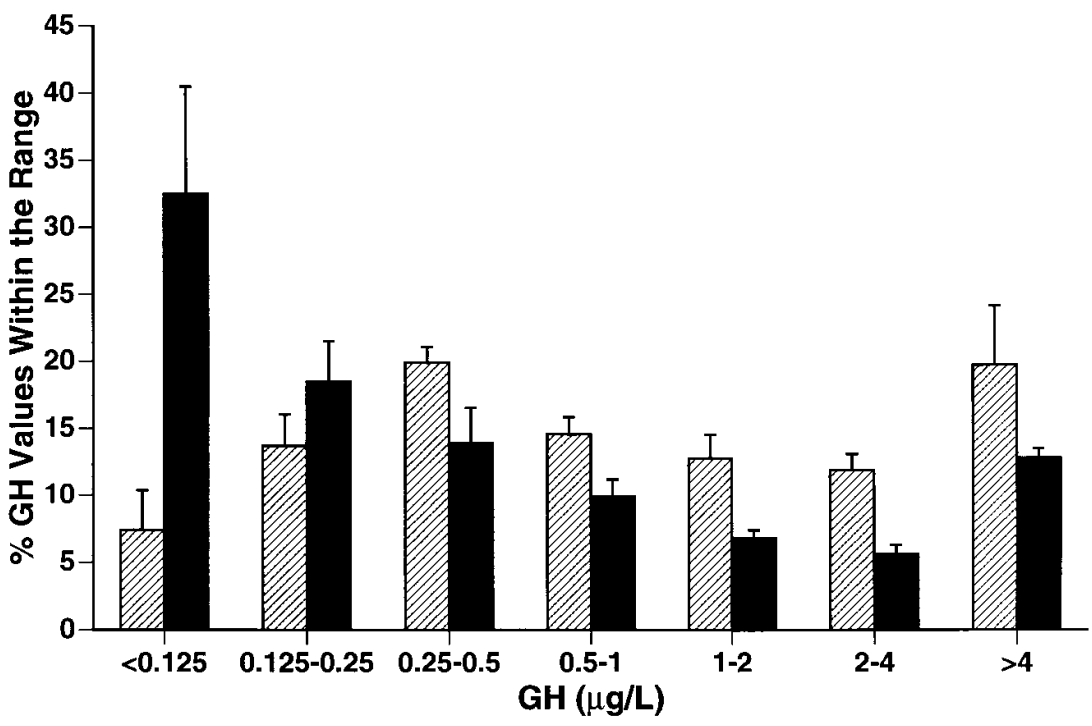

Figure 3. Frequency histograms for plasma GH concentrations in men (black bars) and women (hatched bars). For each subject, the $145 \mathrm{GH}$ measurements obtained during the 24-h sampling period were placed within the bins defined in the figure and the number of values in a particular bin was normalized for the 145 samples. Bars show the mean $( \pm \mathrm{SE})$ percent of GH concentration falling within a particular bin over $24 \mathrm{~h}$. GH concentrations in women exceeded a value of $0.5 \mu \mathrm{g} /$ liter $\sim 50 \%$ more frequently than did GH concentrations in men. quency in each of eight 3-h time blocks. There was both a gender effect $(P=0.002)$ and a time effect $(P=0.0001)$. Women had more pulses than men and the number of GH pulses was greatest for both genders between 2300 and $0200 \mathrm{~h}$. There was also an interaction between the gender and time effects $(P=$ 0.003 ), indicating that the pattern of $\mathrm{GH}$ pulse frequency was different between the two groups, with pulse frequency more evenly distributed over the $24-\mathrm{h}$ study period in women. The analysis of the deconvolution net input (BTI) within these same time blocks is given in the bottom panel. There was a gender effect $(P=0.004)$ and a time effect $(P=0.0001)$ as well as a gender-time interaction $(P=0.0005)$ for BTI. The strong gender-time interaction was a result of a much greater time effect in men $(P=0.0001)$ than in women $(P=0.05)$. The $\mathrm{GH}$ input at each time block, except during the expected nocturnal augmentation of $\mathrm{GH}$, was greater in women than in men, suggesting that women secrete GH more continuously throughout the day, whereas men have predominantly nocturnal GH secretion. This was further demonstrated by deconvolution analysis, which estimated that active secretion occurred $42 \pm 4 \%$ of the time in women but only $24 \pm 2 \%$ of the time in men $(P=0.003)$.

Effect of rhIGF-I on plasma IGF-I and IGFBP-3 concentrations and $G H$ secretion. Mean IGF-I concentrations for the six men and seven women who received $10 \mu \mathrm{g} / \mathrm{kg} / \mathrm{h}$ rhIGF-I are shown in Fig. 5. At baseline, the IGF-I concentrations for the two groups were similar $(231 \pm 21$ vs. $262 \pm 25 \mu \mathrm{g} /$ liter; $P=$ $0.4)$. Approximately $8 \mathrm{~h}$ after the infusion was started, the concentration curves for men and women began to diverge and after $20 \mathrm{~h}$ a plateau in IGF-I concentration was reached for both sexes. Mean IGF-I concentrations during the 0800-0800-h blood sampling period were lower in men than in women (1089 \pm 41 vs. $1389 \pm 99 \mu \mathrm{g} / \mathrm{liter} ; P=0.02$ ). Before the rhIGF-I infusion, plasma IGFBP-3 concentrations were identical in the two groups $(3.00 \pm 0.07$ vs. $3.02 \pm 0.24 \mathrm{mg} / \mathrm{liter} ; P=0.9)$. Although GH secretion fell during rhIGF-I infusion, plasma IGFBP-3 actually increased in men $(P<0.005)$ and there was a trend for higher levels in women.

The effects of rhIGF-I infusion on GH concentration in men (left) and women (right) is shown in Fig. 6 and discrete pa- rameters of pulsatile $\mathrm{GH}$ secretion for the six men and seven women who received rhIGF-I are given in Table II. In both sexes, infusion of rhIGF-I suppressed pulsatile GH secretion and both total 24-h IGHC and pulse frequency were significantly lower during rhIGF-I treatment. The degree of suppression, however was gender specific and the same dose of rhIGF-I resulted in $84 \pm 3 \%$ suppression of the 24 -h IGHC in men, but only $64 \pm 6 \%$ suppression in women $(P=0.007)$. A comparison between the effect of rhIGF-I on the deconvolution output showed that suppression of GH secretion was similarly sexually dimorphic and that the degree of suppression on the calculated secretion was virtually identical to IGHC suppression. rhIGF-I had no effect on GH half-life as calculated by deconvolution.

GH responses to GHRH (Fig. 7). By ANOVA, there was no gender effect on the GH response to GHRH during the control study. There was, however an interaction between gender and treatment. The GH response to the GHRH bolus was significantly attenuated in men by the rhIGF-I infusion $(18.66 \pm 2.98$ vs. $3.88 \pm 0.74 \mu \mathrm{g} / \mathrm{liter} ; P=0.01)$, with a mean suppression of $75 \pm 9 \%$. In contrast, rhIGF-I infusion had no effect on the women's GH response to GHRH (19.69 \pm 6.30 vs. $24.22 \pm 8.14 \mu \mathrm{g} /$ liter; $P=0.6$ ). There was no correlation between the degree of suppression of spontaneous and GHRH stimulated $\mathrm{GH}$ secretion.

Effects of rhIGF-I on thyroid hormones and sex steroids (Fig. 8, Table III). By two-way ANOVA, there were no gender effects on T4, T3, T3RU, or TSH. Hence, in subsequent analyses, data from men and women were combined. rhIGF-I had no effect on T4 or T3RU, however it resulted in an increase in T3 $(101 \pm 7.8$ vs. $126.7 \pm 7.0 \mathrm{ng} / \mathrm{dl} ; P=0.001)$, suppression of baseline TSH $(1.51 \pm 0.19$ vs. $0.64 \pm 0.09 \mathrm{mU} / \mathrm{liter} ; P<$ 0.0001 ) and suppression of the TSH increase after the TRH bolus $(6.83 \pm 0.55$ vs. $4.41 \pm 0.61 \mathrm{mU} /$ liter; $P<0.0001)$. The mean degree of suppression of the TSH response to TRH was $37 \pm 9 \%$ in men and $39 \pm 8 \%$ in women. rhIGF-I had no effect on the concentrations of sex steroids in men. In women, baseline $\mathrm{E} 2$ and $\mathrm{P}$ concentrations were appropriate for early follicular phase and, in comparison to the control study, plasma E2 and $\mathrm{T}$ concentrations were significantly higher during the 

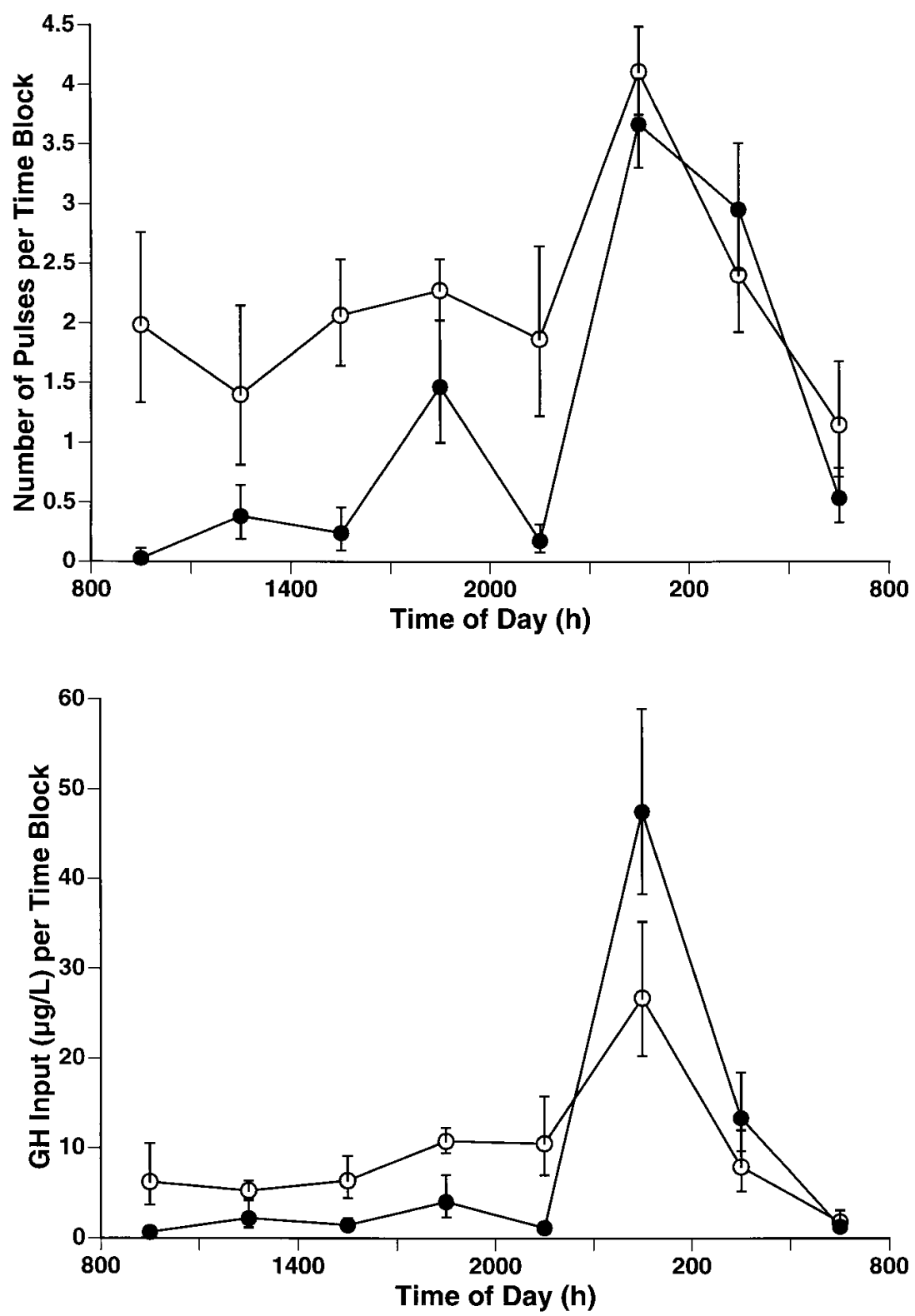

Figure 4. BPF (top) and BTI (bottom) for men $(\bullet)$ and women $(\bigcirc)$ over $24 \mathrm{~h}$. To determine whether there were gender or time effects on GH secretion, the 24-h deconvolution-generated GH secretion data were divided into eight 3-h time periods. Individual BPF and BTI were calculated as the deconvolution-estimated pulse frequency and $\mathrm{GH}$ secretion during each time block respectively. Repeated-measures ANOVA was used to compare GH pulse frequency and secretion across time and genders. Women had more pulses than did men and the number of pulses was greatest for both genders during the 2300-0200-h time period. Although GH secretion was augmented at night in both genders, there was a time-gender interaction and the time effect was much greater in the men, indicating that pulsatile $\mathrm{GH}$ secretion was more uniform over the 24-h period of sampling in the women.

rhIGF-I treatment. rhIGF-I infusion had no effect on $\mathrm{P}$ concentrations

\section{Discussion}

This study demonstrates the existence of sexual dimorphism in the regulation of GH secretion. We show that gender-related differences are manifested by the patterns of GH secretion, rather than the total daily $\mathrm{GH}$ secretion. Moreover, we show that there are striking gender-related differences in the $\mathrm{GH}$ responses to negative feedback by IGF-I.

Several previous studies have suggested that GH secretion in humans is sexually dimorphic, as manifested by higher $\mathrm{GH}$ secretory rates in women $(5,6)$. In contrast to these earlier observations, we found that overall daily $\mathrm{GH}$ secretion rates were similar between men and women. A power analysis using integrated growth hormone concentration in men and women, where the effect size was $0.4 \mathrm{SD}$, suggests that 100 subjects per group would be needed to show a difference with $80 \%$ power. Thus, even if the difference between men and women is real, it is unlikely to be biologically meaningful. A potential explanation for the different conclusions between this and other studies was the age of subjects. In our study, all subjects were between 18 and $30 \mathrm{yr}$ old. In contrast, in other studies $(5,6)$, the subjects were older and the age ranges were wider. Since the age-related fall in $\mathrm{GH}$ secretion is more pronounced in men than in women (17), inclusion of older men would decrease the estimate of mean daily $\mathrm{GH}$ secretion for the male group and might account for the previously reported gender difference.

Our conclusions are supported by a study from Ho et al. (4), which included men and women in an age group similar to that of our study. They reported that higher integrated $\mathrm{GH}$ concentrations in young women were determined by serum estradiol concentrations, not by gender. Since women in our 


\begin{tabular}{|c|c|c|c|c|}
\hline \multirow[b]{2}{*}{ Parameter } & \multicolumn{2}{|c|}{$\operatorname{Men}(n=6)$} & \multicolumn{2}{|c|}{ Women $(n=7)$} \\
\hline & Saline & IGF-I & Saline & IGF-I \\
\hline \multicolumn{5}{|l|}{ Concentration analysis (cluster) } \\
\hline $\operatorname{IGHC}(\mu \mathrm{g} \times \mathrm{min} /$ liter $)$ & $3296 \pm 824$ & $678 \pm 240 *$ & $3770 \pm 688$ & $1246 \pm 232 *$ \\
\hline Pulse frequency (per $24 \mathrm{~h})$ & $9.1 \pm 0.6$ & $5.5 \pm 0.5^{*}$ & $10.4 \pm 0.6$ & $7.4 \pm 0.9^{\ddagger}$ \\
\hline \multicolumn{5}{|c|}{ Secretion analysis (deconvolution) } \\
\hline Secretion $(\mu \mathrm{g} /$ liter $24 \mathrm{~h})$ & $103.4 \pm 26.9$ & $19.6 \pm 7.5^{\ddagger}$ & $107.8 \pm 16.8$ & $37.2 \pm 7.9^{*}$ \\
\hline Pulse frequency (per $24 \mathrm{~h}$ ) & $11.5 \pm 1.3$ & $10.2 \pm 1.2$ & $20.1 \pm 2.6$ & $16.0 \pm 2.3$ \\
\hline Half-life (min) & $17.3 \pm 0.1$ & $16.2 \pm 0.1$ & $18.3 \pm 0.2$ & $18.4 \pm 0.2$ \\
\hline IGFBP-3 (mg/liter) & $3.00 \pm 0.07$ & $3.58 \pm 0.12 *$ & $3.02 \pm 0.24$ & $3.53 \pm 0.27$ \\
\hline
\end{tabular}

$* P<0.005$ saline vs. rhIGF-I. ${ }^{*} P<0.001$ saline vs. rhIGF-I.

study were studied in the early follicular phase, a time when estradiol levels were comparable between the sexes, GH secretion was similar in both groups. Thus, when the study populations were tightly matched for age, relative adiposity, and E2 concentrations, the absolute amounts of GH secreted per day were indistinguishable between men and women.

The positive correlation between plasma E2 and GH secretion in men observed in this study was also consistent with data from Ho et al. (4). Plasma E2 concentrations were uniformly low in the early-follicular phase women and this homogeneity probably obscured any potential correlation between plasma $\mathrm{GH}$ and $\mathrm{E} 2$ concentrations in this group. In order to more conclusively derive a relationship between $\mathrm{GH}$ secretion and sex steroids, studies across the menstrual cycle might be required.

Although the total GH secretion rates were similar in both groups, there were gender-specific differences in the patterns of GH secretion. First, women had more GH pulses as detected both by cluster and by deconvolution analysis. Second, the interpulse $\mathrm{GH}$ levels in women were twice as high as in men, similar to the male vs. female difference found in rats (1).
Third, the temporal organization of the GH pulsatility was different in men and women.

GH secretion in men was characterized by the predominance of large nocturnal pulses and relatively low GH output during the rest of the day. In contrast, women had much more uniform GH pulses throughout the day. This gender-based difference in $\mathrm{GH}$ secretion temporal architecture was demonstrated by frequency histograms. $35 \%$ of GH concentrations in men, but $54 \%$ of concentrations in women exceeded $0.5 \mu \mathrm{g} / \mathrm{li}$ ter, an estimate for the lower limit of biologically meaningful $\mathrm{GH}$. These differences in $\mathrm{GH}$ concentration were shown to originate from different GH secretory patterns. Deconvolution analysis demonstrated that women had more frequent GH secretory events, had more uniform GH secretion throughout the day and spent nearly twice as much time in active $\mathrm{GH}$ secretion than did men.

These differences in GH pulse pattern may subserve possible sex-specific effects of GH. In rodents, sexually dimorphic GH pulse patterns are important for the regulation of many of the metabolic effects of $\mathrm{GH}$, including muscle and cartilage

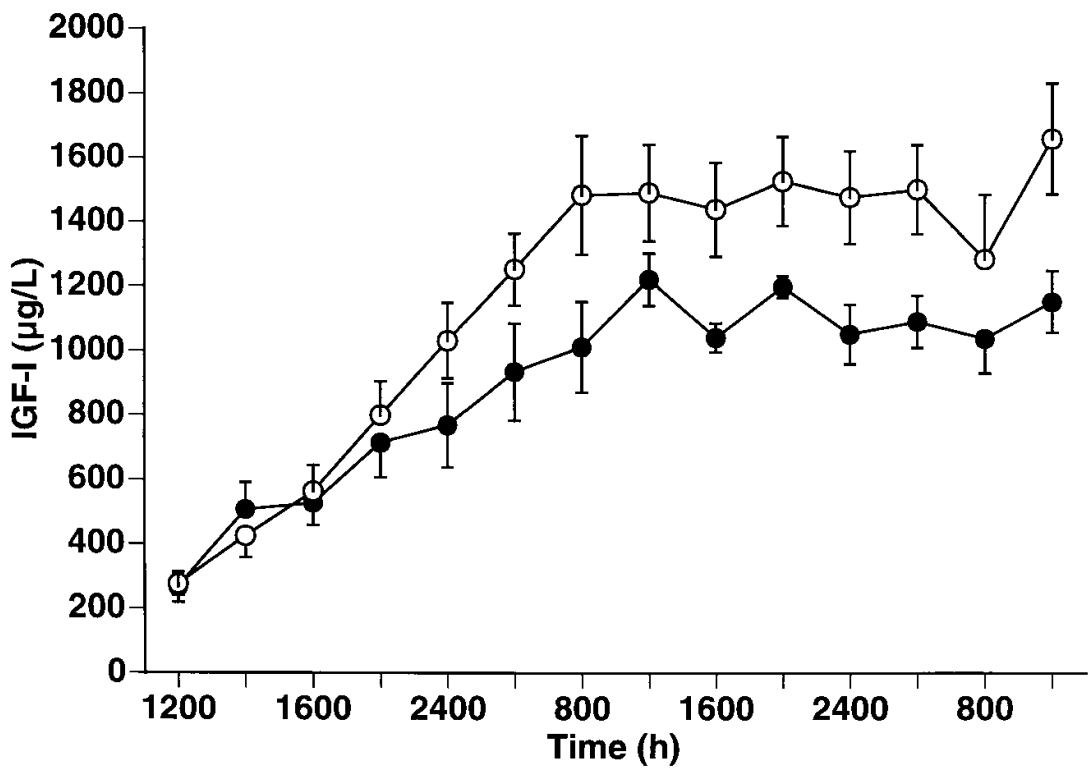

Figure 5. Mean $( \pm \mathrm{SE})$ plasma levels of total IGF-I before and during treatment with rhIGF-I $(10 \mu \mathrm{g} / \mathrm{kg}$ body weight $/ \mathrm{h})$ in six men $(\bullet)$ and 7 women $(\bigcirc)$. 
Table III. Plasma Concentrations of Sex Steroids and Thyroid Hormones in Men and Women during Saline and rhIGF-I Infusions

\begin{tabular}{|c|c|c|c|c|}
\hline \multirow[b]{2}{*}{ Parameter } & \multicolumn{2}{|c|}{$\operatorname{Men}(n=6)$} & \multicolumn{2}{|c|}{ Women $(n=7)$} \\
\hline & Saline & IFG-I & Saline & IGF-I \\
\hline E2 (ng/liter) & $45.3 \pm 10.5$ & $49.6 \pm 11.8$ & $28.8 \pm 6.1$ & $57.4 \pm 8.0^{\ddagger}$ \\
\hline Progesterone $(\mu \mathrm{g} /$ liter $)$ & $0.68 \pm 0.03$ & $0.64 \pm 0.06$ & $0.59 \pm 0.08$ & $0.64 \pm 0.10$ \\
\hline Testosterone ( $\mu \mathrm{g} /$ liter $)$ & $5.89 \pm 0.62$ & $5.85 \pm 0.46$ & $0.36 \pm 0.05$ & $0.46 \pm 0.03 *$ \\
\hline $\mathrm{T} 4(\mu \mathrm{g} / \mathrm{dl})$ & $6.9 \pm 0.4$ & $7.7 \pm 1.1$ & $6.2 \pm 0.5$ & $6.3 \pm 0.5$ \\
\hline T3RU (\%) & $104 \pm 6$ & $97 \pm 4$ & $96 \pm 3$ & $97 \pm 2$ \\
\hline $\mathrm{T} 3$ (ng/dl) & $115 \pm 6$ & $151 \pm 7 *$ & $98 \pm 9$ & $117 \pm 6^{*}$ \\
\hline Baseline TSH (mU/liter) & $1.43 \pm 0.33$ & $0.56 \pm 0.09^{\S}$ & $1.58 \pm 0.24$ & $0.71 \pm 0.15^{\S}$ \\
\hline
\end{tabular}

${ }^{*} P<0.05$ saline vs. rhIGF-I. ${ }^{\ddagger} P<0.01$ saline vs. rhIGF-I. ${ }^{\S} P<0.005$ saline vs. rhIGF-I.

IGF-I mRNA (23), GH receptor mRNA (24), hepatic P450 isoenzymes (2), lipoproteins (25), and somatic growth $(3,26)$. In the case of $\mathrm{GH}$ regulation of hepatic $\mathrm{CYP} 2 \mathrm{C} 11$ and CYP2C12, Waxman et al. (2) have shown that it is neither the total $\mathrm{GH}$ exposure nor the $\mathrm{GH}$ pulse amplitude but rather the interval between pulses that is important for determining which isoform is expressed. Limited data support a role for $\mathrm{GH}$ in the expression of hepatic CYP1A2 in humans (27). In addition, we have previously demonstrated that $\mathrm{GH}$ alters the expression of the $N$-demethylating P450 enzyme CYP3A4; these preliminary data suggested that $\mathrm{GH}$ pulse pattern, not simply total GH secretion was important for this effect (28).
Whether gender-specific GH pulse patterns subserve similar regulation to that found in rodents will require careful clinical investigations. However, the differences in GH secretion and concentration profiles described in our experiments mirror data from animal studies. This provides a physiologic mechanism to explain our previous observations on gender differences in human CYP3A4 expression (28).

We had previously demonstrated that continuous infusion of rhIGF-I to men inhibited pulsatile $\mathrm{GH}$ secretion and the $\mathrm{GH}$ response to a GHRH bolus. We have extended our initial observations by studying whether the same regulatory mechanism holds for women. We found that rhIGF-I was signifi-
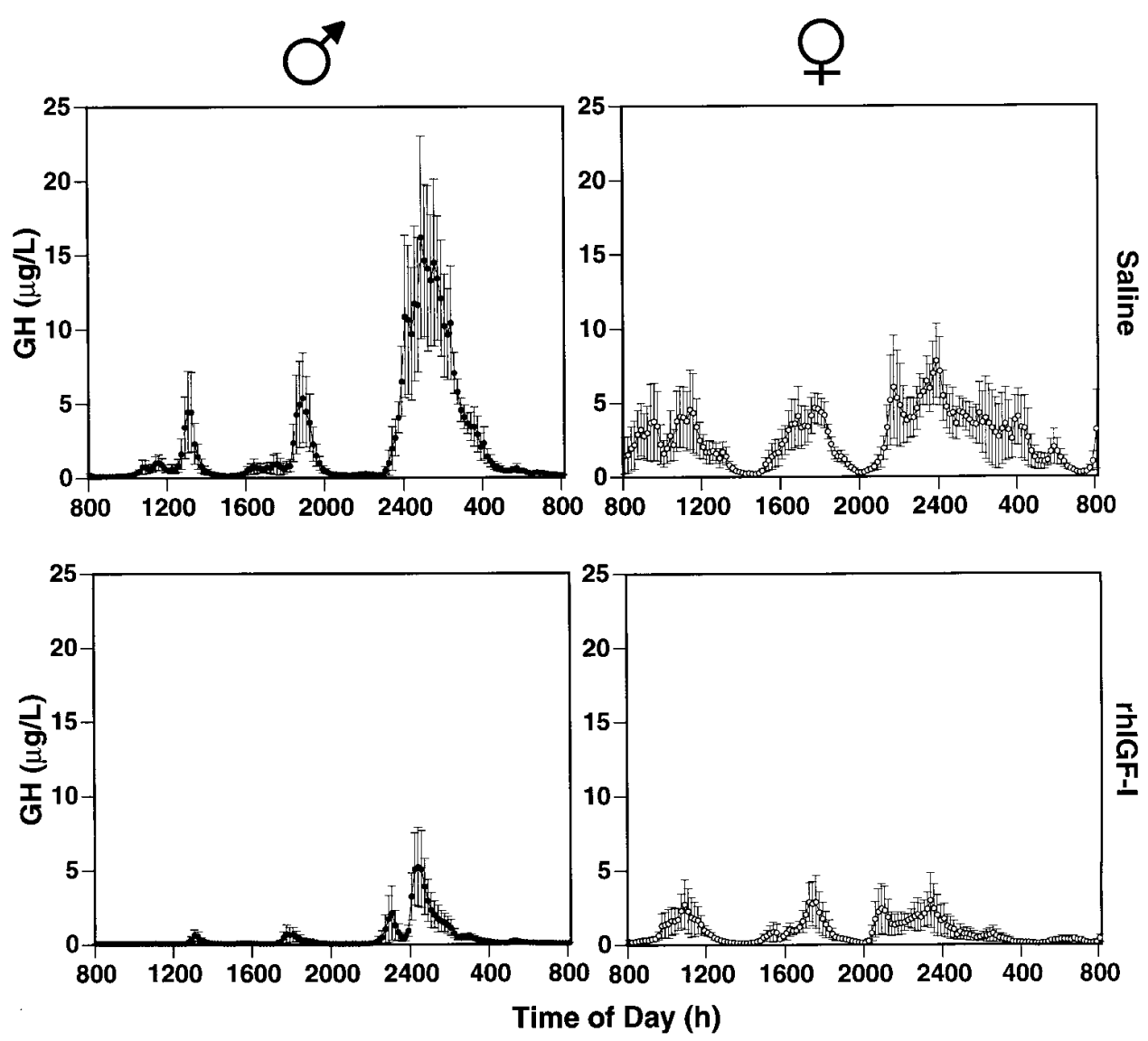

Figure 6. Comparison of plasma $\mathrm{GH}$ concentration profiles (mean $\pm \mathrm{SE})$ in six men (left) and seven women (right) who received $10 \mu \mathrm{g} / \mathrm{kg} / \mathrm{h}$ rhIGF-I i.v. 

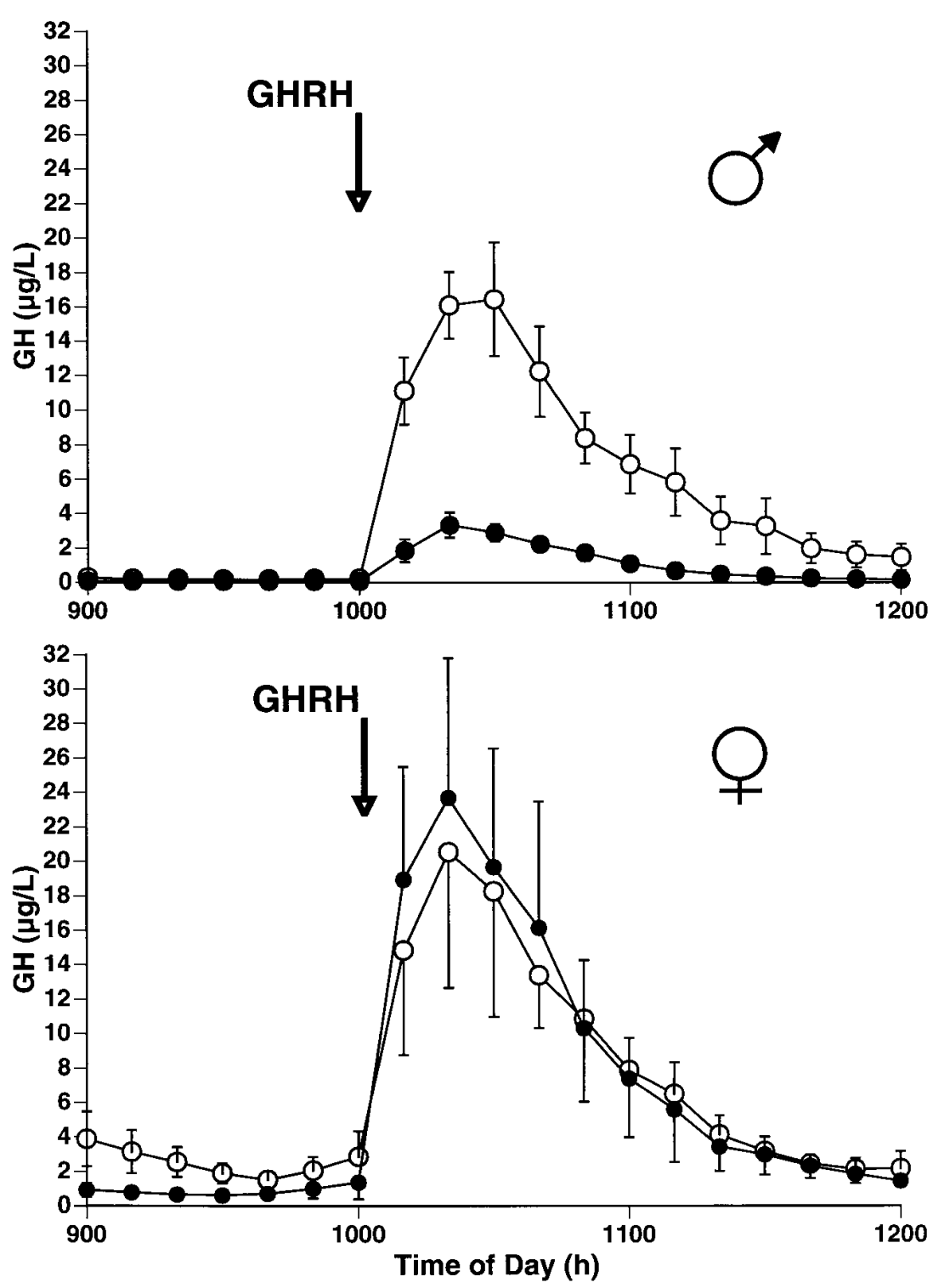

Figure 7. Plasma $\mathrm{GH}$ responses (mean $\pm \mathrm{SE}$ ) to GHRH $(0.33 \mu \mathrm{g} / \mathrm{kg}$ i.v. $)$ in men (top) and women (bottom) during saline $(\bigcirc)$ and rhIGF-I $(\bullet)$ infusions.

cantly less effective in women than in men in terms of inhibiting both spontaneous and GHRH-stimulated GH, despite higher plasma IGF-I concentrations during the rhIGF-I infusion. The higher IGF-I concentrations in women are consistent with less GH suppression in this group so that the total IGF-I during the infusion might have reflected the summation of the rhIGF-I and the residual endogenous IGF-I production. A gender-specific difference in free IGF-I concentrations is unlikely, because plasma concentrations of IGFBP-3, the major IGF-I binding protein, increased more in men than in women during rhIGF-I infusion, suggesting that free IGF-I levels might have been lower in men. It is conceivable that direct pituitary suppression by rhIGF-I (29) is less effective in women. Investigation into this possibility will require in vitro study of normal somatotrophs from men and women.

These data suggest that sexual dimorphism of GH secretion in humans relates to at least two distinct phenomena: different patterns of spontaneous $\mathrm{GH}$ secretion and different suppressibility of spontaneous and GHRH-stimulated GH secretion by rhIGF-I. The neuroendocrine mechanisms that are responsible for these differences have not been fully established. Direct hypophysial-portal sampling in several nonhuman species has suggested that GH pulses are the result of hypothalamic discharges of GHRH (30-32), whereas SRIH likely sets the pituitary responsiveness to GHRH (32). In rats, intermittent secretion of SRIH could explain the periodic responsiveness to GHRH and characteristic GH pulse pattern seen in males of this species (33). This hypothesis is supported by lower levels of hypothalamic SRIH mRNA in female rats (34). In addition, SRIH may be less inducible by negative feedback by GH in females (35). Measurement of GHRH or SRIH in hypothalamic-pituitary blood is not practical in humans and peripheral measurements of these peptides may not reflect hypothalamic secretion. Our previous studies in humans using a specific antagonist to the GHRH receptor $(36,37)$, as well as physiologic experiments demonstrating concordance between GHRH and GH secretion in sheep $(31,32)$ suggest that GHRH and SRIH in higher mammals likely play roles that are parallel to those found in rats.

If this is the case, the gender-related differences in the pat- 

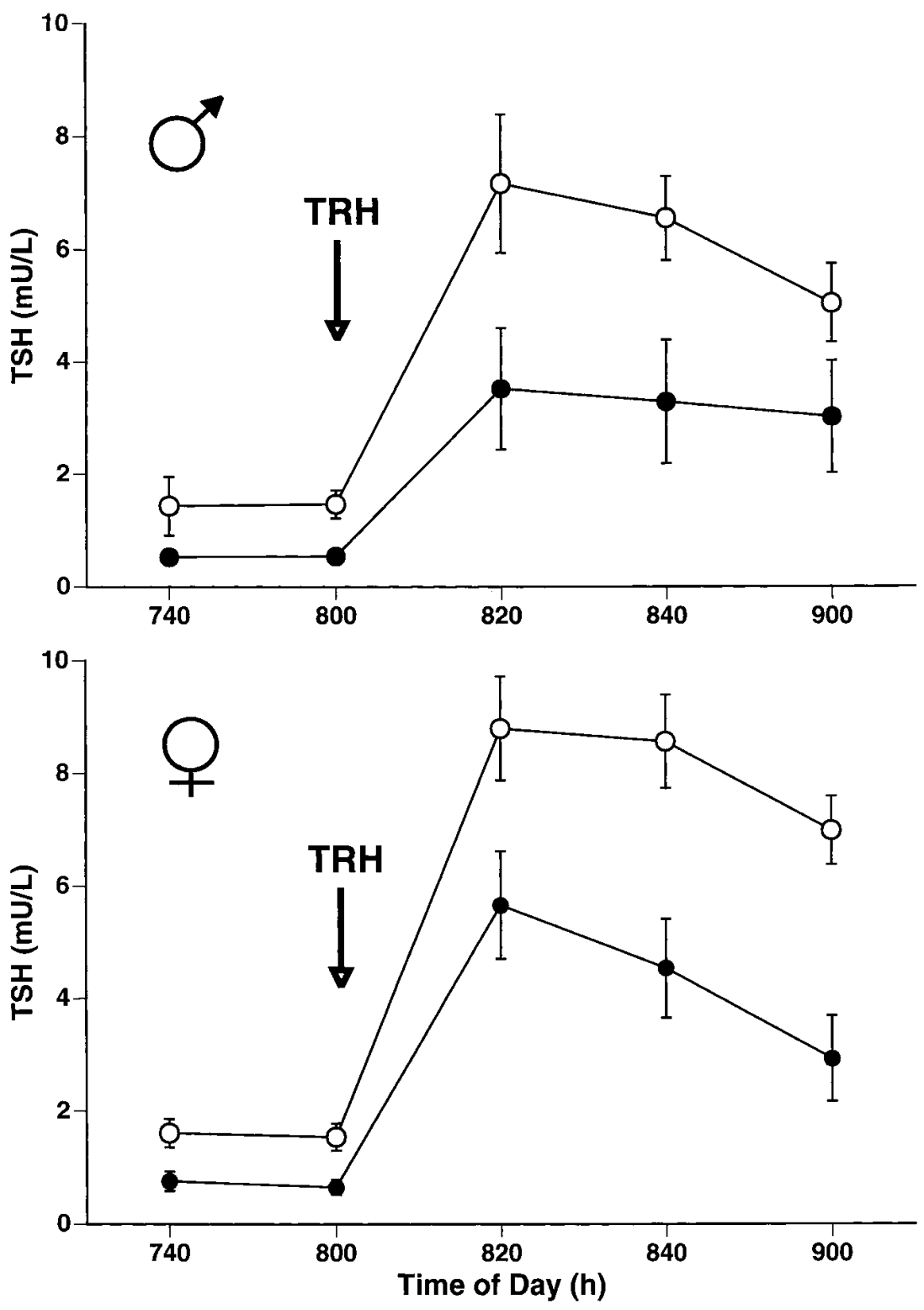

Figure 8. Plasma TSH responses (mean \pm SE) to TRH (50 $\mu \mathrm{g}$ i.v.) in men (top) and women (bottom) during saline $(\bigcirc)$ and rhIGF-I $(\bullet)$ infusions.

tern of GH secretion can be mainly attributed to the lesser role of SRIH in women. This would explain more continuous GH secretion, higher interpulse GH concentrations and the occurrence of more uniform and more frequent $\mathrm{GH}$ pulses in women. Since part of the IGF-I feedback is likely mediated through an augmentation of SRIH secretion (18), the attenuated inhibition of GH secretion by rhIGF-I in women would also support this hypothesis.

rhIGF-I-mediated suppression of spontaneous, but not GHRH-stimulated, GH secretion sets women apart from men, in whom both parameters declined in parallel. The simplest explanation for this difference might be a more prominent suppressive effect of rhIGF-I on GHRH neurons in women. IGF-I negative feedback on GHRH has been described in vitro (38) and was recently suggested by in vivo data in rats (39). This feedback could be sexually dimorphic and our results are similar to studies in rats in which exogenous GH suppressed both spontaneous and GHRH-stimulated GH secretion in males but only GHRH-induced GH release in females $(35,40)$. More powerful effects of SRIH in men could have overshadowed rhIGF-I suppression of GHRH. Moreover, less SRIH effect but similarity in total spontaneous $\mathrm{GH}$ secretion in men and women would require a compensatory decrease in GHRH secretion in women. Indeed, lower levels of GHRH mRNA have been found in hypothalami of female rats (41); median eminence GHRH peptide content is lower in ewes than in rams (42). Taken together, these data suggest that systemic IGF-I inhibits and stimulates hypothalamic GHRH and SRIH, respectively, and that the relative importance of the feedback on GHRH or SRIH neurons is sexually divergent. These interpretations are predicated on a model in which $\mathrm{GH}$ secretion is governed solely by GHRH and SRIH. It is also possible that the endogenous ligand for the recently cloned GH secretagogue receptor (43) plays a role in the sexual differentiation of $\mathrm{GH}$ secretion. Our data may need to be reinterpreted once this ligand is identified and its role in GH physiology is defined. 
Baseline plasma TSH concentrations and TRH-stimulated TSH concentrations were equally suppressed by rhIGF-I infusion in both sexes. We had previously attributed this to a rhIGF-I-induced increase in SRIH (18). Our current data indicate that this might also reflect an increase in T4-to-T3 conversion during the rhIGF-I infusion. In contrast to our results, Klinger et al. (44) found no increase in T3 during rhIGF-I treatment, despite TSH suppression similar to what we observed. Of interest, an increase in T3 has also been found during $\mathrm{GH}$ treatment (45). Given the concomitant fall in plasma $\mathrm{GH}$ in our study, the mechanism of $\mathrm{T} 3$ rise during $\mathrm{GH}$ treatment is probably an IGF-I-mediated $5^{\prime}$-deiodinase effect rather than a result of GH per se. Whether the TSH suppression is due to an increase in SRIH, T3, or both mechanisms is uncertain.

During the rhIGF-I infusion, plasma E2 and T concentrations were higher in women than concentrations obtained during the control infusion. Both studies were performed in the early follicular phase of the menstrual cycle. Increased intraovarian steroid production driven by the systemic rhIGF-I infusion is therefore possible. IGF-I is produced locally in the ovary and may play an important role in ovarian regulation (46). Ovarian IGF-I might be either independent of or in part under the control of systemic GH (46). Our data suggest the intriguing possibility that circulating IGF-I, in addition to locally produced IGF-I, might play a role in intraovarian physiology.

In summary, we have demonstrated the existence of sexual dimorphism of the regulation of GH secretion in humans. This was expressed at a central level and involved both spontaneous GH pulsatility as well as the negative feedback by IGF-I. We attribute this difference primarily to the more prominent role of hypothalamic SRIH in men than in women. Additionally, our data suggest that inhibition of hypothalamic GHRH secretion by IGF-I might play an important role in the control of $\mathrm{GH}$ secretion in women.

\section{Acknowledgments}

We thank the General Clinical Research Center staff for their excellent nursing support and Genentech for providing recombinant human IGF-I.

This work was supported by: Department of Veterans Affairs Merit Review Award (A.L. Barkan), and National Institutes of Health grants R01-DK-38449 (A.L. Barkan), MO1-RR0043-34S3 (Clinical Associate Physician Award to C.A. Jaffe), U54-HD-29184 (C.A. Jaffe), M01-RR0042 (General Clinical Research Center), P60DK-20572 (University of Michigan Diabetes Research Training Center) and the Research Service of the Department of Veterans Affairs.

\section{References}

1. Jansson, J.O., S. Eden, and O. Isaksson. 1985. Sexual dimorphism in the control of growth hormone secretion. Endocrine Rev. 6:128-150.

2. Waxman, D.J., N.A. Pampori, P.A. Ram, A.K. Agrawal, and B.H. Shapiro. 1991. Interpulse interval in circulating growth hormone patterns regulates sexually dimorphic expression of hepatic cytochrome P450. Proc. Natl. Acad. Sci. USA. 88:6868-6872.

3. Clark, R.G., and I.C. Robinson. 1988. Paradoxical growth-promoting effects induced by patterned infusions of somatostatin in female rats. Endocrinology. 122:2675-2682.

4. Ho, K.Y., W.S. Evans, R.M. Blizzard, J.D. Veldhuis, G.R. Merriam, E. Samojlik, R. Furlanetto, A.D. Rogol, D.L. Kaiser, and M.O. Thorner. 1987. Effects of sex and age on the 24-hour profile of growth hormone secretion in man: importance of endogenous estradiol concentrations. J. Clin. Endocrinol. Metab.
64:51-58.

5. Winer, L.M., M.A. Shaw, and G. Baumann. 1990. Basal plasma growth hormone levels in man: new evidence for rhythmicity of growth hormone secretion. J. Clin. Endocrinol. Metab. 70:1678-1686.

6. Van den Berg, G., J.D. Veldhuis, M. Frolich, and F. Roelfsema. 1996. An amplitude-specific divergence in the pulsatile mode of growth hormone $(\mathrm{GH})$ secretion underlies the gender difference in mean $\mathrm{GH}$ concentrations in men and premenopausal women. J. Clin. Endocrinol. Metab. 81:2460-2467.

7. Zadik, Z., S.A. Chalew, R.J. McCarter, M. Meistas, and A.A. Kowarski. 1985. Influence of age on the 24-hour integrated concentration of growth hormone in normal individuals. J. Clin. Endocrinol. Metab. 60:513-516.

8. Pincus, S.M., E.F. Gevers, I.C.A.F. Robinson, G. Van den Berg, F. Roelfsema, M.L. Hartman, and J.D. Veldhuis. 1996. Females secrete growth hormone with more process irregularity than males in both humans and rats. Am. J. Physiol. 270:E107-115.

9. Benito, P., L. Avila, M.S. Corpas, J.A. Jimenez, L. Cacicedo, and F. Sanchez Franco. 1991. Sex differences in growth hormone response to growth hormone-releasing hormone. J. Endocrinol. Invest. 14:265-268.

10. Smals, A.E., G.F. Pieters, A.G. Smals, T.J. Benraad, J. Van Laarhoven, and P.W. Kloppenborg. 1986. Sex difference in human growth hormone (GH) response to intravenous human pancreatic $\mathrm{GH}-$ releasing hormone administration in young adults. J. Clin. Endocrinol. Metab. 62:336-341.

11. Gelato, M.C., O.H. Pescovitz, F. Cassorla, D.L. Loriaux, and G.R. Merriam. 1984. Dose-response relationships for the effects of growth hormonereleasing factor-(1-44)-NH2 in young adult men and women. J. Clin. Endocrinol. Metab. 59:197-201.

12. Arvat, E., M. Cappa, F.F. Casanueva, C. Dieguez, E. Ghigo, M. Nicolosi, R. Valcavi, and M. Zini. 1993. Pyridostigmine potentiates growth hormone (GH)-releasing hormone-induced $\mathrm{GH}$ release in both men and women. J. Clin. Endocrinol. Metab. 76:374-375.

13. Barbarino, A., S.M. Corsillo, A. Tofani, R. Sciuto, S. Della Casa, C.A Rota, and A. Barini. 1991. Sexual dimorphism of pyridostigmine potentiation of growth hormone $(\mathrm{GH})$-releasing hormone-induced $\mathrm{GH}$ release in humans. $J$. Clin. Endocrinol. Metab. 73:75-78.

14. Diamond, M.P., T. Jones, S. Caprio, L. Hallarman, M.C. Diamond, M. Addabbo, W.V. Tamborlane, and R.S. Sherwin. 1993. Gender influences counterregulatory hormone responses to hypoglycemia. Metabolism. 42:1568-1572.

15. Chapman, I.M., M.L. Hartman, M. Straume, M.L. Johnson, J.D. Veldhuis, and M.O. Thorner. 1994. Enhanced sensitivity growth hormone (GH) chemiluminescence assay reveals lower postglucose nadir GH concentrations in men than women. J. Clin. Endocrinol. Metab. 78:1312-1319.

16. Veldhuis, J.D. 1996. Gender differences in secretory activity of the human somatotropic (growth hormone) axis. Eur. J. Endocrinol. 134:287-295.

17. Weltman, A., J.Y. Weltman, M.L. Hartman, R.D. Abbott, A.D. Rogol, W.S. Evans, and J.D. Veldhuis. 1994. Relationship between age, percentage body fat, fitness, and 24-hour growth hormone release in healthy youg adults: effects of gender. J. Clin. Endocrinol. Metab. 78:543-548.

18. Bermann, M., C.A. Jaffe, W. Tsai, R. DeMott Friberg, and A.L. Barkan. 1994. Negative feedback regulation of pulsatile growth hormone secretion by insulin-like growth factor I: involvement of hypothalamic somatostatin. J. Clin. Invest. 94:138-145.

19. Jaffe, C.A., D.K. Turgeon, R. DeMott Friberg, P.B. Watkins, and A.L. Barkan. 1995. Nocturnal augmentation of growth hormone $(\mathrm{GH})$ secretion is preserved during repetitive bolus administration of GH-releasing hormone: potential involvement of endogenous somatostatin. J. Clin. Endocrinol. Metab. 80: 3321-3326.

20. Veldhuis, J.D., M.L. Carlson, and M.L. Johnson. 1987. The pituitary gland secretes in bursts: appraising the nature of glandular secretory impulses by simultaneous multiple-parameter deconvolution of plasma hormone concentrations. Proc. Natl. Acad. Sci. USA. 84:7686-7690.

21. Owens, D., M.C. Srivastava, C.V. Tompkins, N.D.N. Nabarro, and P.H. Sonksen. 1973. Studies on the metabolic clearance rate, apparent distribution space and plasma half-disappearance time of unlabeled human growth hormone in normal subjects and in patients with liver disease, renal disease and diabetes mellitus. Eur. J. Clin. Invest. 3:284-294.

22. Reutens, A.T., J.D. Veldhuis, D.M. Hoffman, K.-C. Leung, and K.K. Ho. 1996. A highly sensitive growth hormone (GH) enzyme-linked immunosorbent assay uncovers increased contribution of a tonic mode of $\mathrm{GH}$ secretion in adults with organic GH deficiency. J. Clin. Endocrinol. Metab. 81:1591-1597.

23. Isgaard, J., L. Carlsson, O.G.P. Isakson, and J.O. Jansson. 1988. Pulsatile intravenous growth hormone $(\mathrm{GH})$ infusion to the hypophysectomized rat increases insulin-like growth factor I messenger ribonucleic acid in skeletal tissues more effectively than continuous GH infusion. Endocrinology. 123:26052610 .

24. Maiter, D., L.E. Underwood, M. Maies, M.L. Davenport, and J.M. Ketelslegers. 1988. Different effects of intermittent and continuous growth hormone $(\mathrm{GH})$ administration on serum somatomedin-C/insulin-like growth factor I and liver GH receptors in hypophysectomized rats. Endocrinology. 123:10531059.

25. Sjoberg, A., J. Oscarsson, S. Eden, and S.O. Olofsson. 1994. Continuous but not intermittent administration of growth hormone to hypophysectomized rats increases apolipoprotein-E secretion from cultured hepatocytes. Endocri- 
nology. 134:790-798.

26. Clark, R.G., J.O. Jansson, O. Isaksson, and I.C. Robinson. 1985. Intravenous growth hormone: growth responses to patterned infusions in hypophysectomized rats. J. Endocrinol. 104:53-61.

27. Levitsky, L., D.A. Schoeller, G.H. Lambert, and D.V. Edidin. 1989. Effect of growth hormone therapy in growth hormone-deficient children on cytochrome P-450-dependent 3-N-demethylation of caffeine as measured by the caffeine 13-CO2 breath test. Dev. Pharmacol. Ther. 12:90-95.

28. Watkins, P.B., D.K. Turgeon, C.A. Jaffe, P.J. Ho, and A.L. Barkan. 1993. Pulsation frequency of growth hormone may mediate gender differences in CYP3A activity in man. Clin. Res. 41:132a.(Abstr.)

29. Berelowitz, M., M. Szabo, L.A. Frohman, S. Firesone, L. Chu, and R.L. Hintz. 1981. Somatomedin-C mediates growth hormone negative feedback by effects on both the hypothalamus and the pituitary. Science. 212:1279-1281.

30. Plotsky, P.M., and W. Vale. 1985. Patterns of growth hormone-releasing factor and somatostatin secretion into the hypophysial-portal circulation of the rat. Science. 230:461-463.

31. Frohman, L.A., T.R. Downs, I.J. Clarke, and G.B. Thomas. 1991. Measurement of growth hormone-releasing hormone and somatostatin in hypothalamic-portal plasma of unanesthetized sheep. J. Clin. Invest. 86:17-24.

32. Thomas, G.B., J.T. Cummins, H. Francis, A.W. Sudbury, P.I. McCloud, and I.J. Clarke. 1991. Effect of restricted feeding on the relationship between hypophysial portal concentrations of growth hormone $(\mathrm{GH})$-releasing factor and somatostatin, and jugular concentrations of $\mathrm{GH}$ in ovariectomized ewes. Endocrinology. 128:1151-1158.

33. Painson, J.C., and G.S. Tannenbaum. 1991. Sexual dimorphism of somatostatin and growth hormone-releasing factor signaling in the control of pulsatile growth hormone secretion in the rat. Endocrinology. 128:2858-2866.

34. Chowen-Breed, J.A., R.A. Steiner, and D.K Clifton. 1989. Sexual dimorphism and testosterone-dependent regulation of somatostatin gene expression in the periventricular nucleus of the rat brain. Endocrinology. 125:357-362.

35. Carlsson, L.M., R.G. Clark, and I.C. Robinson. 1990. Sex difference in growth hormone feedback in the rat. J. Endocrinol. 126:27-35.

36. Jaffe, C.A., R. DeMott-Friberg, and A.L. Barkan. 1993. Suppression of growth hormone $(\mathrm{GH})$ secretion by a selective GH-releasing hormone (GHRH) antagonist. Direct evidence for involvement of endogenous GHRH in the generation of GH pulses. J. Clin. Invest. 92:695-701.

37. Jaffe, C.A., R. DeMott Friberg, and A.L. Barkan. 1996. Involvement of endogenous growth hormone $(\mathrm{GH})$-releasing hormone in the $\mathrm{GH}$ responses to physiological and pharmacological stimuli. J. Clin. Invest. 97:934-940.

38. Shibasaki, T., N. Yamauchi, M. Hotta, A. Masuda, T. Imaki, H. Demura, N. Ling, and K Shizume. 1986. In vitro release of growth hormone-releasing factor from rat hypothalamus: effect of insulin-like growth factor-1. Reg. Pept. 15:47-53.

39. Becker, K., S. Stegenga, and S. Conway. 1995. Role of insulin-like growth factor I in regulating growth hormone release and feedback in the male rat. Neuroendocrinology. 61:573-583.

40. Clark, R.G., L.M. Carlsson, and I.C. Robinson. 1988. Growth hormone (GH) secretion in the conscious rat: negative feedback of GH on its own release. J. Endocrinol. 119:201-209.

41. Maiter, D., J.I. Koenig, and L.M. Kaplan. 1991. Sexually dimorphic expression of the growth hormone-releasing hormone gene is not mediated by circulating gonadal hormones in the adult rat. Endocrinology. 128:1709-1716.

42. Gatford, K.L., T.P. Fletcher, A. Rao, A.R. Egan, B.J. Hosking, and I.J. Clarke. 1997. GH, GH-releasing factor and somatostatin in the growing lamb: sex differences and mechanisms for sex differences. J. Endocrinol. 152:19-27.

43. Howard, A.D., S.D. Feighner, D.F. Cully, J.P. Arena, P.A. Liberator, C.I. Rosenblum, M. Hamelin, D.L. Hreniuk, O.C. Palyha, J. Anderson, P.S. Paress, C. Diaz, M. Chou, K.K. Liu, K.K. McKee, S.-S. Pong, L.-Y. Chaung, A. Elbrecht, M. Dashkevicz, R. Heavens, M. Rigby, D.J.S. Sirinathsinghji, D.C. Dean, D.G. Melillo, A.A. Patchett, R. Nargund, P.R. Griffin, J.A. DeMartino, S.K. Gupta, J.M. Schaeffer, R.G. Smith, and L.H.T. Van der Ploeg. 1996. A receptor in pituitary and hypothalamus that functions in growth hormone release. Science. 273:974-977.

44. Klinger, B., A. Ionesco, S. Anin, and Z. Laron. 1992. Effect of insulinlike growth factor I on the thyroid axis in patients with Laron-type dwarfism and healthy subjects. Acta Endocrinol. 127:515-519.

45. Jorgenson, J.O.L., S.A. Pedersen, P. Laurberg, J. Weeke, N.E. Skakkebaek, and J.S. Christiansen. 1989. Effects of growth hormone therapy on thy roid function of growth hormone deficient adults with and without concomitan thyroxine-substituted central hypothyroidism. J. Clin. Endocrinol. Metab. 69: $1127-1132$.

46. Katz, E., E. Ricciarelli, and E.Y. Adashi. 1993. The potential relevance of growth hormone to female reproductive physiology and pathophysiology. Fertil. Steril. 59:8-34. 